\title{
HERE BE SPIES: MCCARTHYISM, ITS RECEPTION AND CONNECTIONS TO THE IMAGE OF THE USSR IN THE US BETWEEN 1947-1954
}

\author{
JIŘÍ PONDĚLÍČEK
}

\begin{abstract}
The paper deals with the era known as McCarthyism in the context of the early Cold War. It focuses on how the Americans perceived the threat of domestic Communists and how their view was linked to the events abroad. Using poll data from Gallup Polls conducted in and around the years in question, it discusses the cause and effect relation between the public opinion and the hearings. The paper concludes that the negative and sometimes hostile opinion of Americans toward Communism was not caused by McCarthyism, but it rather worked as a catalyst for the politicians who wanted to build their career on the issue of Communist subversion. When the external factors helped ease the domestic tension, the careers of McCarthy and others collapsed.
\end{abstract}

Keywords: Cold War, United States, McCarthyism, public opinion, communism, anti-communism DOI: $10.14712 / 23363231.2015 .78$

\section{Introduction}

In the minds of average Americans, the early Cold War was dominated by two things: the atomic bomb and the spies. The fear of subversive activities of the communists at home was not new to the US public in 1947. The Red Scare which gripped Americans after the Second World War had been preceded by the first Red Scare between 1919 and 1921. In the same way, the infamous House Un-American Activities Committee, HUAC, which investigated the political affiliations of regular citizens, entertainers and governmental employees, had been foreshadowed by the Dies committee operating between 1938 and 1944. However, neither of these 
spurred as much controversy as the later anti-communist crusade. To this day, authors writing on this topic are deeply divided mainly among ideological lines: liberals tend to see it as one great abomination and a dark age for civil liberties, while conservatives defend it as necessary means to rid the government and the society of disloyal elements. Those condemning it as a witch-hunt choose more absurd allegations and accusations to paint the picture of an era of paranoia. Those defending it point out that many of those alleged communist spies had in fact been working for the USSR. Surprisingly, one does not necessarily contradict another.

On the one hand, it is true that the spectacular investigation of Hollywood in 1947 and the public interest it sparked had little to do with the communist infiltration in the higher echelons of the US government. The theatrical aspect of the proceedings are reflected in the extensive media coverage of this extravaganza and the cultural paranoia that made it possible to end the careers of screenplay writers, actors and producers because of their suspicious opinions or past associations with communist movements. On the other, the infiltration of the US government was not a mere fantasy. ${ }^{1}$

McCarthyism then was both an effort to find spies and potential threats within the US government apparatus and an exercise in propaganda campaigning. For Nixon, the part he played in HUAC gained him much popularity and was in effect a stepping-stone to the Vice Presidency. Additionally, ideologically and culturally subversive groups, though benign as a security threat, became viable targets: left-wing academics, union members and leaders, civil rights activists, and homosexuals. The anti-communist crusaders were often accused of racism and anti-semitism. This does not seem implausible given the fact that J. Edgar Hoover, the head of the FBI, "hated Slavs, Jews, Catholics, homosexuals."2 McCarthy himself was accused of being an anti-semite.

Furthermore, it is true that the general suspicion towards alien elements in the society was nothing new in American history. As Richard Fried puts it: "In a nation groping for identity, opponents of radicalism naturally sought to curb immigration, on the theory that immigrants carried dangerous ideas." ${ }^{3}$ There had been Alien and Sedition Acts before and the immigrants and foreigners, whether Catholics or Jews, had been affected deeply by the Red Scare after the First World

1 See John Earl Haynes and Harvey Klehr, Venona: Decoding Soviet Espionage in America (New Haven, CT: Yale University Press, 1999), Kindle edition.

2 Jonathan Miles, The Nine Lives of Otto Katz (London: Transworld Publishers, 2010), Ch. 12, Kindle edition.

3 Richard M. Fried, Nightmare in Red: The McCarthy Era in Perspective (New York: Oxford University Press, 1999), Ch. 2, Kindle edition. 
War. There is more evidence to support the fact that anti-semitism was, at least partly, a driving force behind the identification of the subversives. Six out of the Hollywood ten were Jewish. Professor Joseph Litvak from Tufts University, for example, argues that the Jewish origin of the victims played a significant role. ${ }^{4}$

This paper does not intend to conceal, condone, or even justify these transgressions. It should be stated here and now that the hunt for spies had its very ugly side and its many innocent victims. These, however, are not the focus of the paper. Neither is it to describe or judge all the individual cases. The scope of the paper alone forbids such a mammoth task. Moreover, it has been done by many authors before ${ }^{5}$ and the controversy in some cases still persists.

However, some cases like the famous Hiss-Chambers case deserve a little closer attention. Not only because there are many even today who believe that Hiss was innocent despite the fact that the Venona files and the Soviet archives point to the opposite conclusion. ${ }^{6}$ There are two more interesting cases, that of Harry White and Judith Coplon. The first two cases show us how their handling by the HUAC made the question of guilt and innocence an ideological battleground for many years to come. The third one shows that the hunt for spies was not limitless.

This will complement the main focus of the paper, which is to try and assess what was fueling the witch-hunt, how strong the popular support for the hearings was, and last but not least, how the image of the USSR influenced the process and was influenced by it. The research questions which I tried to ask myself are implied by these three areas. First, what was the moving force? The hunt was conducted by the politicians, but did they create or rather satisfied the demand for it? Second, how strong or weak were the support for some action and the support for the course of action taken by the politicians? Third, how did the hunt for spies and communists in all walks of life instill, enforce or make use of the image of the USSR as a hostile power? The questions should be answered by a short study organized on a loose chronological basis.

The paper is a historical study using results of sociological research. Apart from a selection of secondary literature, I will mostly use the results of Gallup polls conducted in and around the years in question. These will serve to illustrate the opinion of Americans towards Communism, the Soviet Union, HUAC hearings, and

4 See Joseph Litvak, The Un-Americans: Jews, The Blacklist, and Stoolpigeon Culture (Durham: Duke University Press, 2009).

5 See M. F. Toinet, transl. Hana Hurtová, Hon na čarodejnice (Praha: Themis, 1999); Ellen W. Schrecker, Many are the Crimes (Boston, MA: Little, Brown and Company, 1998); and Ellen W. Schrecker, Age of McCarthyism (New York: Palgrave, 2002).

6 See Haynes and Klehr, Venona: Decoding Soviet Espionage, Ch. 5, Friends in High Places. 
McCarthy's activities. They should illustrate how the influence of McCarthyism was always dependent on the outside factors: tension with the Soviets, Soviet atomic test, loss of China, and Korean War.

For the sake of clarity and consistency, the term McCarthyism in this paper is used to describe all the anti-communist activities including those that had occurred before the senator's rise to fame. However, since the public seem to have reacted differently to investigations in different areas, I will make a distinction between the investigations of communist subversion in the entertainment industry and the investigations concerning government offices and spies.

\section{The Show's Opening}

The year 1947 brought about the widely publicized Hollywood hearings and loyalty oath program for the government employees. Doherty describes the first HUAC meeting as a "political-cultural fandango more akin to a gala premiere at Grauman's Chinese Theater than a somber legislative inquiry."7 The hearings started on 20 October and the first "unfriendly" witness, John Howard Larson, testified for the first time on 27 October. The same month, on 22 October, a poll was conducted by Gallup in which nearly $58 \%$ of respondents agreed that there were many communists in Hollywood and $48 \%$ that the communists frequently got their propaganda into movies. In both cases there were fewer of those who answered "no" than those who had no opinion: $18 \%$ to $24 \%$ and $22 \%$ to $26 \%$ respectively. ${ }^{8}$ It is clear from these results that the atmosphere was rather unfriendly towards the communists in the industry, real or presumed, when the hearings started.

However strongly people felt about the need to purge Hollywood of communists, they did not unanimously accept the harsh methods of HUAC. According to Gallup data, $43 \%$ of those who had heard about the Congressional Committee's investigation agreed that the writers who had refused to say whether they had been members of the Communist party (CPUSA) should be punished, 39\% thought they should not and $18 \%$ did not have any opinion. ${ }^{9}$ There are two ways of looking at these results. The $43 \%$ who supported the punishment for artists whose only crime was that they had declined to state their political affiliation is quite a high figure. However, in the era of anti-communist paranoia and fear, as it is often described, the $39 \%$ who valued the concept of the freedom of speech in the first amendment

7 Thomas Doherty, Cold War, Cool Medium: Television, McCarthyism, and American Culture (New York: Columbia University Press), Ch. 2, Kindle Edition.

8 The Gallup Poll \#406, q. 14a, 14b (October 1947), in the Gallup Brain.

9 The Gallup Poll \#407, q. 11d (May 1947), in the Gallup Brain. 
higher than mitigating a threat, the existence of which they believed, is a relatively high number as well. Therefore, while there was a solid consensus on the goals, there was none on the means.

Some authors, like Albert Fried, blame the growing anti-communist zeal on the congressional elections in 1946. Fried claims " $[\mathrm{t}]$ he rise of McCarthyism owed much to the smashing Republican victory of 1946. [...] It was of major significance that they achieved their victory at the expense of Northern and Western liberals [...]; Southern Democrats [...] as usual suffered no losses. Congress was now very conservative." 10 This is why HUAC, which had existed before, became more active. However, the Republican victory itself was a result of deep anti-communist feeling within the American society. In 1946, Republicans did not play the red card because they had won the election, but they won the election because they had played the red card. At that time, Americans were already expressing unfriendly or openly hostile opinions towards communism and the Soviet Union. For instance, $49 \%$ thought that the members of the Communist party are loyal to Russia, while only $24 \%$ considered them loyal to America and $27 \%$ had no opinion. In the same poll, $80 \%$ expressed a belief that Russia had spies in the US and 69\% thought that communists should not be permitted to hold civil service jobs. ${ }^{11}$ This poll was conducted in July of that year, i.e. before the election.

The prevailing anti-communist and anti-Soviet sentiment in the society was only reflected in the 80th Congress; the increased number of Republicans in the Congress was a result rather than a cause of the sentiment. This does not contradict the fact that the more active Congress, or its HUAC public shows, reinforced this sentiment in the American people. This seems clear from the poll data from before and after Congress started its public show. In March 1949, 70\% of Americans thought that the membership in the CPUSA should be forbidden by law and that figure had actually risen from October 1947, when 61\% of Americans had expressed the same belief. Furthermore, the figure had been similarly high much earlier before, in May 1941. ${ }^{12}$ In the same fashion, the number of those who would bar the members of the Party from holding Civil Service jobs rose from 69\% in March 1947 to 84\% in February 1949. ${ }^{13}$ While these increases are by no means insignificant, the figures had been consistently high even before the activities of HUAC started. The communists only received a temporary and partial pardon

\footnotetext{
10 Albert Fried, McCarthyism: The Great American Red Scare, A Documentary History (New York: Oxford University Press, 1997), 23.

11 The Gallup Poll \#375, q. 7a, 7b, 7e (July, 1946), in the Gallup Brain.

12 Gallup polls \#237 (May 1941), \#406 (October 1947) and \#438 (March 1949), in the Gallup Brain.

13 Gallup polls \#393 (March 1947) and \#437 (February 1949), in the Gallup Brain.
} 
from the American people during the Second World War. This indicates that the American public was more resistant to the propaganda aspect of the hearings and exercised much more common sense than popularly believed.

The first Hollywood hearings and the case of the Hollywood Ten, while undoubtedly stirring the public opinion, did not cause immediate and widespread hysteria or paranoia. The situation for the communists, however, was becoming worse. Historian Richard Fried claims that the landmark year in this process was 1949. He writes that "the fragile political balance that kept anti-communism in check in 1948 crumbled in the next two years as remote events bumped aside bosses and in-laws as concerns of the average Joe." 14 The worsening of the international situation, the Soviet atomic test and the loss of China harmed the image and the situation of the American communists more than any campaign could have done. The hearings continued and the blacklist grew. The popular opinion did not react to this with hysteria, though. The hostility towards the CPUSA had been high since 1946, as we have seen. The real extravaganza came with the man whose name serves today as the label of the era, but McCarthy gave his infamous Wheeling speech only in 1950 when the situation had become ripe. The question is, then, what had made it ripe.

\section{The Cold War and the Public}

The anti-communist crusade and public opinion influenced and at times reinforced each other rather than one being caused by the other. This is not to say that the hearings before HUAC were the best way to assuage the public opinion, or that it was legal to prosecute actors and screenwriters based on an affiliation to a party. It is just to say that these hearings reacted to the public demand for something to be done. Of course, propaganda might have been responsible for the general dislike of communism and communists, but there are other possible, and more plausible, explanations. Vladislav M. Zubok points out that the cause for the hostility was in fact Stalin's behavior on the world stage. He writes: “Stalin's pressure on Iran, combined with his belligerence toward Turkey, put the Soviet Union on a collision course not only with the Truman administration but also with broad segments of American public opinion." 15 This is another argument against the overwhelming influence of the Congressional anti-communist crusade on the public. It is

\footnotetext{
14 Richard M. Fried, Nightmare in Red, Ch. 4.

15 Vladislav M. Zubok, Failed Empire: The Soviet Union in the Cold War from Stalin to Gorbachev (Chapel Hill, NC: University of North Carolina Press, 2007), Ch. 2, Kindle edition.
} 
likely that it was Stalin's actions that turned Americans against communism and the communists at home and abroad, while the Republican red-baiting campaign made use of that already existing sentiment.

Furthermore, the Republican Party was not the only one who jumped on the bandwagon. Historian Richard Fried claims that the "GOP [Grand Old Party, the Republicans] had no monopoly on the issue. The Democrats did their own red-baiting, chiefly of Wallace and his party." 16 Wallace certainly was a suitable target. In fact, $51 \%$ of respondents of a poll conducted in June 1948 agreed that Wallace's Third Party is run by communists. Only $23 \%$ of them disagreed. This judgment seems too harsh on Wallace, but the fact remains that he was the only influential supporter of cooperation with the Soviet Union despite Stalin's aggressive policy towards Poland, Turkey and Iran. Zubok explains that "the most influential friends were gone [by the beginning of 1946]. Roosevelt's death and the subsequent departure of Harry Hopkins, Henry Morgenthau, Harold Ickes, and the other New Dealers forever ended the Soviet Union's 'special relationship' with the United States. The last ally Stalin had in the US Government was [...] Henry Wallace." 17

In his speech "The Way to Peace" Wallace succeeded in appearing both a proponent of realpolitik in the international relationships and a hopeless idealist regarding the Soviet intentions. On the one hand, he claimed that "on our part, we should recognize that we have no mare [sic] business in the political affairs of Eastern Europe than Russia has in the political affairs of Latin America, Western Europe and the United States." ${ }^{18}$ This is something that might have helped to ease Stalin's paranoia at that time by reaffirming the respective spheres of influence. On the other hand, Wallace also stated that

the two ideas [capitalism and communism] will endeavor to prove which can deliver the most satisfaction to the common man in their respective areas of political dominance. But by mutual agreement, this competition should be put on a friendly basis and the Russians should stop conniving against us in certain areas of the world just as we should stop scheming against them in other parts of the world. ${ }^{19}$

16 Richard M. Fried, Nightmare in Red, Ch. 3.

17 Zubok, Failed Empire, Ch. 2.

18 Henry A. Wallace, “The Way to Peace," New York, September 12, 1946, New Deal Network, http:// newdeal.feri.org/wallace/haw28.htm.

19 Ibid. 
In September 1946, this seemed as nothing more than wishful thinking. Wallace was swept aside by the same wave of feelings as the proponents of the Hollywood Ten and other real or alleged communists in the entertainment industry. Just as it was enough to end careers in show business when one did not firmly deny being or having been a communist, being soft on the Soviet Union was enough to end political careers. Having accepted an endorsement from the CPUSA, Wallace received just $2.37 \%$ of the popular vote and no Electoral Votes. ${ }^{20}$

Communism as a political force, never having been strong in the US, was almost completely defeated at the end of the 1940s. However, it continued to play an important part in the public life in a different way; as the image of the enemy both inside and outside, real and fictional. The members of the CPUSA were considered a liability at best and traitors at worst. In the Gallup Poll \#373 from 1946, the Americans were asked what should be done with the communists in the US. $24 \%$ said they did not know and $18 \%$ thought they should be left alone. When the same question was asked two years later in the Gallup Poll \#418T, the respective figures were $16 \%$ and $9 \%$. The number of those who answered that Communists should be shot rose from $3 \%$ to $21 \%{ }^{21}$ It is questionable whether $21 \%$ would really support summary executions of the CPUSA members, but the growing tendency towards harsher remedies is obvious. However, the figures also show that there was no significant increase in those supporting some kind of action against the domestic Communists. Close examination of the results seems to indicate that while there was an increase in the number of those favoring a violent solution to the problem, the ratio between supporters of some legal action and those who did not want to do anything or at least take no legal action remained roughly the same.

There were twelve possible answers in that survey. Of those twelve, seven refer to some legal action being taken against the communists, three do not and two can be considered neutral. The two neutral are: no answer and a miscellaneous answer. The three moderate are: do nothing, should not encourage them, and let them rave but watch them. The seven calling for one form of legal action or another are: curb them, keep them out of governmental offices, try to get rid of them, deport them, shoot them or hang them, jail them, and outlaw them. The neutral group scored

20 Of course, this poor result could have been caused by his other controversial views such as his opposition to segregation. This certainly made him unpalatable to the Southern Democrat voters, but a staunch segregationist Strom Thrumond fared only marginally better in the elections: $2.4 \%$ of the popular vote. Therefore, it seems safe to say that this was not a decisive issue for most voters. The red-baiting against civil rights activists, however, remains an interesting and shameful chapter in the US history.

${ }^{21}$ Gallup polls \#373 (June 1946) and \#418T (May 1948), in the Gallup Brain. 
$25 \%$ in 1946 and $20 \%$ in 1948 . The second, moderate group of answers were chosen by $24 \%$ of the respondents in 1946 and $22 \%$ in 1948 . The last group of answers gained support of $51 \%$ of the people asked in 1946 and $58 \%$ in $1948 .{ }^{22}$ There is a shift, but certainly not as dramatic as the one from $3 \%$ to $21 \%$ in the support of executions. The radicalization is clear and the anti-communist campaign is the usual suspect. However, it seems that there was a movement towards extremity among those who had already supported some action before the hearings started rather than a radical shift of balance between the two groups.

American anti-communism negatively affected many. Also, the campaign against the reds was used to silence or at least marginalize other dissenting voices in the public discourse. Richard Fried claims "[a]dvocates of peace, civil rights, and other causes had the growing burden of proving that they were not acting as 'fronts' for of 'dupes' of communism. [...] To be leftist was to be suspect.". ${ }^{23}$ At the time, when anti-communist and anti-Soviet sentiment ran high, it was tempting to label one's opponent as a communist and thus turning the public against him or her. Furthermore, condemning scores of actors and actresses, writers, and teachers merely for being communists or members of communist affiliated groups was an act that damaged the American concept of civil liberties more that the communists could have ever done. There is, however, an important difference between artists and educators and government officials, which the Americans seem to have respected and which is often overlooked.

At the time of a severe crisis or conflict, the sensitivity towards the rights of those who stand on the other side weakens. This has happened more than once in the American history, but the late 1940s and early 1950s seem to occupy a privileged position in the American conscience. The American concept of civil liberties does present a problem in dealing with opposition and dissent during a conflict. One such example is the suspension of the habeas corpus in Maryland at the outset of the Civil War. Lincoln defended his decision by saying: "Are all the laws, but one [the right of habeas corpus], to go unexecuted [...] and the government itself go to pieces, lest that one be violated." 24 While this caused much controversy at the time, it does not present a contentious topic today. Our tolerance for such exceptions depends on how serious we consider the threat to be and as we shall see later, the threat of communist infiltration of the government was all too real in the late 1940s. Granting that the methods of HUAC served little to shed light on

22 Gallup polls \#373 (June 1946) and \#418T (May 1948), in the Gallup Brain.

${ }^{23}$ Richard M. Fried, Nightmare in Red, Ch. 4.

${ }^{24}$ James McPherson, Battle Cry of Freedom (New York: Oxford University Press, 1988), Ch. 9, Kindle edition. 
the communist subversion of the government, as would be demonstrated later, it is hard to deny that the government had the right to protect itself against the people who were secretly working towards its doom, which is something the Americans understood better than the prosecution of screenplay writers and artists.

\section{Loyalty Oaths and the Question of Government Infiltration}

The starting gun fired in 1947 when President Truman announced his loyalty program. Fried even labeled it "the key moment in the second Red Scare" 25 and he connects it more with Truman's foreign agenda than with the domestic policy when he claims that "without such a pledge to fight communists at home, the penny pinching, isolationist Republican Congress was unlikely to muster enthusiasm for fighting the Red menace abroad." 26 While Truman's plea in Congress for money for the Greek and Turkish governments and the program both occurred in March 1947, it is hardly conclusive evidence. John Earl Haynes provides another explanation why Truman started the program long after he had received information about the possible risks from the FBI. He claims "in late 1945 and in 1946, the White House had reacted with a mixture of indifference and skepticism to FBI reports [...]. By early 1947, however, this indifference ended. The accumulation of information from defectors [...], along with the Venona decryptions made senior Truman administration officials realize the reports of Soviet spying constituted more that FBI paranoia." 27

Truman himself expressed his concern with the possible subversion of the US government. During a press conference on 3 April 1947, he was asked a question about his having called the communist threat a "bugaboo." He said: "I am not worried about the Communist Party taking over the Government of the United States, but I am against a person, whose loyalty is not to the Government of the United States, holding a Government job." 28 In his statement on the program on 14 November 1947, he repeated this by saying: "I believe I speak for all the people of the United States when I say that disloyal and subversive elements must be removed from the employ of the Government." ${ }^{29}$ Truman was pushed by both

${ }^{25}$ Richard M. Fried, Nightmare in Red, Ch. 3.

${ }^{26}$ Ibid.

27 Haynes and Klehr, Venona: Decoding Soviet Espionage, Ch. 1.

28 President's News Conference, April 3, 1947, Truman's Presidential Library, http://www.trumanlibrary .org/publicpapers/index.php?pid=2178\&st=loyalty\&st1 $=$.

${ }^{29}$ Harry S. Truman, "Statement on the Government's Employee Loyalty Program," November 14, 1947, Truman's Presidential Library, http://www.trumanlibrary.org/publicpapers/index .php?pid=1865\&st=\&st $1=$. 
Republicans and his fellow Democrats to adopt his measures by necessity and the support for these was much stronger than for cultural subversion purges. Some even pushed him to pursue a more vigorous and aggressive policy.

The chairman of HUAC, who also tried the Hollywood Ten, J. Parnell Thomas wrote Truman a public letter on 23 April, a month after the loyalty program was announced. In it, he urged Truman to "step in and take a hand in this matter and direct your Attorney General to throw the full weight of his Department behind an effort." ${ }^{30}$ Truman's answer was very short, consisting of three sentences only one of which dealt with the subject matter. He wrote: "I think you will find the Attorney General will do his duty as it should be done and in the interest of the welfare of the United States." 31 However, Truman did not budge; the loyalty program remained relatively sensible both in its size and method. The same cannot be said about the hearings of HUAC. The purging of Hollywood was a mere overture to the most famous hearings of Harry Dexter White, Lauchlin Currie, and Alger Hiss. The three cases were sensational and spur controversy even to this day. Richard Fried is undoubtedly justified to say that "trials, like other political acts, have an educational (or theatrical) function." 32 As Doherty claims and as we shall see in the examination of Hiss-Chambers case, these trials undoubtedly did. This fact, however, does not rule out that they were, in fact, aiming at correct targets.

The question whether the infiltration of the government was real or just imagined, a result of the paranoid atmosphere of the early Cold War, is not a mere technicality. Even accepting that the methods of HUAC were doubtful at best, it still makes a difference whether there was a real basis for the allegations or they were all smoke and mirrors. As it has been argued earlier, agreeing that the threat is real weakens the insistence on the civil liberties, for better or worse. Americans believed this threat was real. But, was it justified?

Hayes argues that for many years, many influential authors denied any validity to the claims saying that "communists were depicted as innocent victims of an irrational and oppressive American Government." $33 \mathrm{He}$ also argues that this is simply not true, claiming that "while not every Soviet spy was a communist, most were. And

30 J. Parnell Thomas, "Letter to Harry S. Truman," April 23, 1947, Truman's Presidential Library, http://www.trumanlibrary.org/whistlestop/study_collections/loyaltyprogram/documents/index .php? pagenumber $=3 \&$ documentdate $=1947-04-25 \&$ documentid $=10-11$.

31 Harry S. Truman, "Letter to J. Parnell Thomas," April 25, 1947, Truman's Presidential Library, http://www.trumanlibrary.org/whistlestop/study_collections/loyaltyprogram/documents/index .php?pagenumber $=1 \&$ documentdate $=1947-04-25 \&$ documentid $=10-11$.

32 Richard M. Fried, Nightmare in Red, Ch. 4.

33 Hayes and Klehr, Venona: Decoding Soviet Espionage, Ch. 1. 
while not every American Communist was a spy, hundreds were." 34 In August 1948, right after the first testimonies of White and Hiss before HUAC, $60 \%$ of those who heard about the Congressional investigations agreed that there was something to it. ${ }^{35}$ It seems now that this was a justified fear. ${ }^{36}$

As it has been mentioned, there are three cases that are particularly interesting for the purpose of this paper. The limited scope of this paper does not allow us to examine the cases in detail and the topic of the article does not require it. It will suffice to describe how handling the cases planted a seed of controversy and mistrust harvest of which we have been reaping ever since.

Of the three cases, Coplon is the only one in which the person was tried in court for the actual crime of spying. Her case was quite important for two reasons. Firstly, as Richard Fried puts it, "[the trial] embarrassed the FBI, showing it had investigated such menaces as Henry A. Wallace supporters, Hollywood leftist, even the author of a thesis on the New Deal in New Zealand." ${ }^{7}$ Secondly, it proved that while the legislative inquiry may have been much too eager to condemn the reds, the judicial system worked. Coplon appealed and both sentences were overturned because of the FBI's illegal activities during the investigation. Fried writes "the indictment stood and Coplon's guilt seemed obvious, but she was set free by the demands of due process." ${ }^{8}$ Even at the height of the early Cold War tension ${ }^{39}$ and even in the very strong case against Coplon, courts did not freely sacrificed due process.

This seemingly insignificant detail is the greatest single demonstration of the difference between McCarthyism and the political show-trials in the USSR and its East European satellites, to which it is often compared. Democracy cannot prevent hostility towards political groups viewed as alien and adversary. Neither can it prevent shrewd politicians from exploiting such sentiments. It makes it much harder for said politicians to hijack the system to serve the one overriding principle. It may not make much of a difference to the victims whose lives and careers were ruined, but it should to a scholar. The judicial system, with some exceptions, still honored legal process. HUAC, as a legislative body, obviously did not have to adhere to the same standards. In the cases of White and Hiss, the public trials

34 Ibid.

35 Gallup Poll \#423K, q. 10d (August 1948), in the Gallup Brain.

36 See Alexander Vassiliev and Alex Weinstein, The Haunted Wood: Soviet Espionage in America - Stalin Era (New York: Random House, 2000); and Jonathan Miles, The Nine Lives of Otto Katz (London: Transworld Publishers, 2010).

${ }^{37}$ Richard M. Fried, Nightmare in Red, Ch. 4.

38 Ibid.

39 The trials and appeals took place between 1949 and 1951, the time of the loss of China, the Soviet atomic test, and the Korean War. 
before the committee were much more emotional than Coplon's, but again, their creating a mass hysteria in the American public is questionable.

\section{Alger Hiss: A Botched Job}

Harry Dexter White had been a subject of interest to the FBI long before he was accused of being a Soviet agent. On 8 November 1945 the FBI informed the president through his aide about the suspicion. In July and August 1948, White was accused of giving information to the Soviets by Elizabeth Bentley and Whittaker Chambers. He appeared before the committee himself on 13 August and denied the charges. A few days after that, he died. To those who opposed the Congressional hearings or those who saw it as a political battleground, White became a martyr, "a victim, said his friends, of HUAC's hazing." 40 Many on the left saw his case as a part of a smear campaign against New Deal, just as they did with Alger Hiss and just as some see it now. Richard Fried says: "Throughout the Eightieth Congress, HUAC sought to discover the ties that it firmly suspected ran from Communist Party headquarters to the New Deal's inner sanctums." 41 That may be so, but the fact remains that some prominent New Dealers did not have a clear conscience.

Furthermore, it may be said that if destroying the image of the New Deal through linking it with communist subversion was the goal of HUAC, it failed miserably. In a survey of May 1952, when asked which type of presidential candidate they would favor, $63 \%$ of respondents answered that "one who claims some of the [...] New Deal and [...] Fair Deal policies have been good for the country and some [...] bad." 42 At the same time, $19 \%$ would favor a candidate who claimed that almost all of them had been good and just $13 \%$ the one who claimed that almost all of them had been bad. New Deal and Fair Deal were not divisive issues in 1952 at the height of McCarthy's demagogic crusade. Americans were not turned against the New Deal and the New Dealers; they were turned against Communists.

While White died so shortly after his testimony that it would have been impossible to decide his guilt or innocence, even if HUAC had had the means to do so. The case of Alger Hiss remained in the spotlights for most of the period discussed in this paper. Both cases are similar in that the dispute over their guilt has persisted to the present. This paper does not try to bring any new information to the questions of guilt. Suffice it to say that Tony Judt, who can hardly be accused

\footnotetext{
${ }^{40}$ Richard M. Fried, Nightmare in Red, Ch. 3.

41 Ibid.

42 Gallup Poll \#493, q. 15 (May 1952), in the Gallup Brain.
} 
of being biased against liberals, once wrote that "for those who do not believe in fairies, the Hiss affair is now closed." 43 Furthermore, the allegations that were at the time hard if not impossible to prove were actually confirmed by both the declassified Venona files and the research in Moscow archives. ${ }^{44}$ The same could not be said about the case of Harry White.

The more interesting question is how HUAC handled the case from the theatrical aspect and how this helped or hindered the quest for truth. The whole extravaganza of the hearings started in 1948 and coincided with the birth of the most influential mass media of the second half of the twentieth century, the television. Doherty points out how symptomatic the first televised broadcasts from Congress were: "On November 11, 1947, WMAL-TV [...] telecast testimony from Secretary of State George C. Marshall before the Senate Foreign Relations Committee. [...] On August 25, 1948, the first telecast from the House [...] offered another preview of coming attractions: the inquiry [...] into the accusations by ex-communist Whittaker Chambers that Alger Hiss, [...], had operated as a Soviet agent in the 1930s." 45 While the TV audience at that point was marginal compared with radio listeners and cinema goers, the publicity given to this trial was, nevertheless, substantial. The first testimony by Chambers was broadcast and filmed for newsreels; when Hiss refuted his allegations on 5 August he, despite being filmed, complained "[d]enials do not always catch up with charges." 46 To which Mr. John McDowell, representative from Pennsylvania, replied "[B]ut I think they will in your case." ${ }^{77} \mathrm{He}$ was right; the hearings became a spectacle first on the radio and in the cinemas and, not long after that, on television. Hiss was granted his chance to deny the charges.

The whole drama achieved little in terms of clarifying the role of Alger Hiss in the presumed spy ring. This was due to the fact that HUAC could only work in a very limited space and relied most heavily and almost exclusively on the testimonies. Even with this limited space, however, the committee worked surprisingly inefficiently.

43 Tony Judt, "An American Tragedy? The Case of Whittaker Chambers," in Reappraisals: Reflections on the Forgotten Twentieth Century (New York: The Penguin Press, 2008), 299.

${ }^{44}$ See Vassiliev and Weinstein, The Haunted Wood, Ch. 12; and Eduard Mark, "In Re Alger Hiss: A Final Verdict from the Archives of the KGB," Journal of Cold War Studies Vol. 11, No. 3 (Summer 2009): 26-67.

45 Doherty, Cold War Cool Medium, Ch. 6.

46 Alger Hiss, Testimony before HUAC, August 5, 1948, University of Missouri - Kansas City (hereafter cited as Hiss's Testimony, August 5, 1948, UMKC), http://law2.umkc.edu/faculty/projects /ftrials/hiss/8-5testimony.html.

47 Ibid. 
The results of the HUAC hearings in Hiss-Chambers case were inconclusive; Chambers' testimony was corroborated by some other witnesses, but generally he offered no proof. Judt writes that "when Chambers repeated his charges [...] on a radio program, without the benefit of the legal protection [...], Hiss sued him for slander on September 27, 1948. Obliged now to come up with something more [...], Chambers finally [...] affirmed that Alger Hiss and others had been engaged in espionage. He backed his claim by [...] documents and microfilms." ${ }^{48}$ Only after that the evidence was strong enough to try Hiss by a grand jury for perjury. Before the Committee, the two men could have argued for hours, days and even months without offering any conclusive proof; Chambers repeating his testimony and Hiss producing new and new character witnesses for him.

The questions of HUAC did not help much either. The best example is Mr. Mundt's asking Hiss about the Yalta conference:

Mr. Mundt: Did you participate in those parts which gave Russia three votes in the Assembly?

Mr. Hiss: I was present at the conference and am familiar with some of the fact involved in that particular arrangement.

Mr. Mundt: You would say you did participate in the formation of that part of the agreement?

Mr. Hiss: I had nothing to do with the decision that these votes be granter. I opposed them. ${ }^{49}$

This answer, obviously, could not have been either confirmed or refuted before the Committee, since the documentation about this was still classified. Hiss easily scored points without having to prove anything. Mr. Mundt had had a similar stroke of brilliance two days before that when questioning Chambers.

Mr. Mundt: As communism is now directed by Stalin from Moscow and as his tactics are now carried out, how would you differentiate between Stalin's communism and Hitler's nazism?

\footnotetext{
48 Judt, "An American Tragedy?" 301.

49 Hiss's Testimony, August 5, 1948, UMKC.
} 
Mr. Chambers: I should find that very difficult to do. I would say that they are most totalitarian forms of government, if you like. I feel quite unable to answer that. ${ }^{50}$

This had nothing to do with the case, invoked the interrogated to formulate his opinion towards the whole ideology rather than to enlighten the investigators about certain facts. This question, and others like it, was an inevitable result of the hearing being a public political spectacle, but it did little to invoke confidence in HUAC. Mostly, it seemed that the whole ideology was on trial. The dilettantism of HUAC is, however, in itself not a proof of Hiss's innocence. It just shows us how dependent the belief in the guilt of Alger Hiss and many others became on the factors connected to the procedure and people involved. The truth did not matter much, as the whole case turned into an emotional popularity contest.

John Earl Haynes writes "[s]ince the information about Soviet espionage and American Communist participation derived largely from the testimony of defectors and a mass of circumstantial evidence, the public's belief in those reports rested on faith in the integrity of government security officials." ${ }^{1}$ This was true for one of the members of HUAC more than for the others. Nixon was one of the most pursuant and active members of HUAC during his time in it and during this case in particular. Nixon himself understood the importance of the publicity for the hearings and the outcomes. He admitted in 1971 in a conversation about a different topic that HUAC "won the Hiss case in the papers. We did. I had to leak stuff all over the place. Because the Justice Department would not prosecute it. Hoover didn't even cooperate. [...] It was won in the papers." 52 All these factors combined and the matter of Hiss's guilt became more a question of a public consensus rather than a judicial decision. This backfired in the years after Watergate. It is as Richard Fried writes: "As Nixon's star dimmed, Hiss's flickered anew." 53

However, it was Nixon himself who invoked the ghost of the closed case first. In 1952, he used TV and the wide publicity that the activities of the Committee granted him to his personal political goal. As the press at that time acknowledged, he succeeded. Doherty quotes from the article in Variety about that interview. It reads: "If Senator Richard M. Nixon isn't elected Vice President, he can always get a job as a TV actor. [...] He turned in the kind of a job that should have had GOP

50 Whittaker Chambers, Testimony before HUAC, August 3, 1948, University of Missouri - Kansas City, http://law2.umkc.edu/faculty/projects/ftrials/hiss/8-3testimony.html.

${ }^{51}$ Hayes and Kehler, Venona: Decoding Soviet Espionage, Ch. 1.

52 Stanley Kutler, ed., Abuse of Power: The New Nixon Tapes (New York: The Free Press, 1997), Pt. 1, Kindle edition.

${ }^{53}$ Richard M. Fried, Nightmare in Red, Ch. 1. 
adherents gleeful at their sets and the Demos gnashing in frustration." 54 Although Nixon tried to revive the publicity of the trial that had happened two years before his interview and he admittedly succeeded at this, the time of the Committee had already passed and a new star rose among the publicly well-known anti-communists, Senator Joseph McCarthy. McCarthy gave a new impetus to the Hollywood investigation and also to the hunt for spies and communists within the government agencies. While the HUAC hearings were in no way immune to demagogic arguments and disrespect for civil liberties, McCarthy easily surpassed it in both respects. This was, paradoxically, the reason for both his great success and his fall.

\section{The Climax: McCarthy Rises in Bad Times}

McCarthy's vigorous anti-communist campaign did not create the anti-red sentiment in the US, much like HUAC had not done before him. Nevertheless, it is clear from the surveys quoted above that he came to an arena where anti-communism was predominant and well accepted. Yet, it was rather a consequence of the international situation development. Just as the American public had lost any kind of sympathy for the communist cause in 1946 and 1947 due to Stalin's ruthless foreign policy, it entered the frenzied state of mind in 1949 and 1950 because of the events on the international stage. In a survey conducted in August 1948, 55\% of the respondents believed that there would be another big war in ten years. $41 \%$ of those who answered "yes" also thought that the responsibility for starting the war would rest on Russia, Soviet Russia, the USSR, communist countries, or Stalin. The second most frequent opinion expressed with just $4 \%$ was that groups of people, factions, capitalists, politicians, communists, political parties, Negroes, or Labor would cause the war. ${ }^{55}$ Those figures alone show a high level of mistrust towards the USSR and communism.

The public opinion grew more hostile in the following two years. In a poll from January 1949, only 17\% of respondents believed that the Russian government sincerely desired peace and $72 \%$ thought it did not. Almost a half believed that the war with Russia was just a matter of time. ${ }^{56}$ That was the beginning of the year during which the Americans were to face two great shocks which presumably may have provided McCarthy the window of opportunity. First came the Soviet atomic test. Hayes claims that "when the Soviet Union exploded a nuclear device

\footnotetext{
54 Doherty, Cold War Cool Medium, Ch. 5.

55 Gallup Poll \#423K, q. 6a, 6b (August 1948), in the Gallup Brain.

56 Gallup Poll \#435K, q. 3a, q. 3 b (January 1949), in the Gallup Brain.
} 
in 1949, ordinary Americans as well as the nation's leaders realized that [...] Stalin had just gained the power to destroy cities at will. This perception colored the early Cold War with the hues of apocalypse." ${ }^{57} 44 \%$ of people believed that this had made another war more likely. ${ }^{58}$ Again, whether the test itself gave Stalin the power to destroy cities is doubtful at best, but the shock of it undoubtedly contributed to McCarthy's rise. The second event was the emergence of the communist People's Republic of China.

As has been already pointed out, McCarthy started his career as a media shooting star by his speech at Wheeling, West Virginia. In this speech, the senator produced, from the propagandist point of view, a perfect mixture of fear-mongering and hope-offering. He painted a bleak picture of the outside world that is becoming increasingly communist and more and more hostile towards the American way of life. He stated the following: "Six years ago [...] there was within the Soviet orbit 180,000,000 people. Lined up on the anti-totalitarian side there were in the world at that time roughly $1,625,000,000$ people. Today [...] there are $800,000,000$ people under the absolute domination of Soviet Russia [...]. On our side, the figure has shrunk to around 500,000,000." 59 However shaky the figures were, ${ }^{60}$ they had an effect. After establishing that there is a clear and present danger and that communism is on the rise, McCarthy started pointing at the culprits. There were many of them and there were to be many more in the next four years.

The whole four years of McCarthy's crusade have been thoroughly studied and described; it is not necessary to repeat the well known facts here. Furthermore, this paper is concerned with the public reaction to it, rather than the proceedings themselves. It is enough to say that he employed the same methods even more ruthlessly and targeted the same groups of people, mostly government employees and artists. When the senator made his charges, the reaction of the public was mostly favorable. Three months after his speech, $88 \%$ of Americans had heard about his charges and $68 \%$ thought that there was something to those charges. ${ }^{61}$ That certainly seems as an overwhelming approval, but contrary to the popular belief, there were serious doubts both about his charges and his methods right from the start. In June 1950, a poll was conducted in which $31 \%$ of those

\footnotetext{
${ }^{57}$ Hayes and Kehler, Venona: Decoding Soviet Espionage, Ch. 1.

58 Gallup Poll \#449, q. 4a (October 1948), in the Gallup Brain.

59 Joseph McCarthy, "Speech at Wheeling," February 9, 1950, George Mason University, http://historymatters.gmu.edu/d/6456.

60 Clearly, it was China tipping the balance. However, what he meant by the "antitotalitarian" front is unclear and China's belonging to such a league less clear still.

${ }^{61}$ Gallup Poll \#455, q. 3a, q 3b (April 1950), in the Gallup Brain.
} 
respondents who had heard about McCarthy's charges expressed approval with them, $12 \%$ thought that there had to be a foundation for them but that they are greatly exaggerated, and $22 \%$ did not believe them at all. ${ }^{62}$

This does not seem as widespread hysteria; many people simply did not jump on the bandwagon, even though they considered the danger to be real and many more did not even believe there was any threat at all. McCarthy did achieve a political success with his accusations, because even though he was unable to prove his charges, the suspicion stuck and for some Americans that was enough. This was clear in the case of Owen Lattimore, as Richard Fried writes: "Though McCarthy could not confirm his charges against Lattimore, the Democrats [on the Tydings Committee] had a hard time proving the negative - Lattimore's innocence." 63 While the $31 \%$ believing the charges completely may not be a majority, it can prove to be a decisive factor if they rally behind one of the parties in the American politied system and if they consider the topic important. McCarthy did not need to be loved by all and he certainly was not. In July 1951, 58\% of Americans either did not have an opinion on McCarthy or did not know him at all. A guarter held unfavorable or qualified unfavorable opinions and just $16 \%$ held favorable or qualified favorable opinions. It seems that many of those who believed there was a grain of truth in his allegations did not agree with his style and demagogy. However, McCarthy's influence on the issue had significant ramifications in a different way.

It has been established that due to unfavorable international development and foreign policy setbacks the sense of impending crisis had been strongly implanted into the American public by the early 1950s. It is clear how high the communist issue was on the minds of Americans from a poll conducted in March 1952 in the anticipation of the elections. The respondents were shown a list of twelve possible actions of the future president and they were supposed to choose the three most important to them. $36 \%$ selected cleaning out communism in the US; it was the second most frequent answer. ${ }^{64}$ McCarthy may not have helped to raise the awareness of the issue, because it had been prominent even before his entry on the stage. Nevertheless, he gathered a group of supporters who cared little for how the cleaning out process would be conducted, and they viewed everyone who criticized this process with suspicion. This made him virtually untouchable within the Republican Party.

${ }^{62}$ Gallup Poll \#456, q. 4b (June 1950), in the Gallup Brain.

63 Richard M. Fried, Nightmare in Red, Ch. 5.

${ }^{64}$ Gallup Poll \#488, q. 13 (March 1952), in the Gallup Brain. 
Dwight Eisenhower offers one explanation for this in a letter he wrote on 18 May 1953 to Mr. Harry Bullis. He writes "this particular individual wants, above all else, publicity. Nothing would probably please him more than to get the publicity that would be generated by public repudiation by the President." 65 While denying McCarthy publicity could have been a valid strategy, in 1953 it was already too late for that. Richard Fried points out that Eisenhower "knew that many Republicans respected McCarthy. [...] With the Republicans holding control of Congress by only a thin margin [...], Ike sought to avoid alienating any members of his party." 66 In other words, the Republicans could have been hurt just as easily by the communist issue and they may have wanted just to avoid similar split as the Democrats had seen in 1947 and 1948. Either way, the Republican Party was too weak to get rid of McCarthy by its own power. In the end, his fall was preconditioned by the same thing that had enabled his rise; the international situation.

In the years following WWII, Stalin and his policy was the root cause for the reemergence of political anti-communism as a major political force. In the same way, Stalin's death was the single most important event behind the decline of this political force. Shortly after his death, the unpopular Korean War ended and as Albert Fried puts it: "It was a situation hardly conductive to McCarthy's political well being." ${ }^{67} \mathrm{His}$ fall, however, was not immediate. The support for McCarthy and his methods had been far from universal or even overwhelming even at the time of the crisis. In 1953, these figures began to decline and in 1954 they literally plummeted.

Apart from the easing of the tension between the US and the USSR, McCarthy experienced another setback in 1953. In July, J. B. Matthews was forced to resign from a position of a research director. Mr. Matthews had written an article called "Reds and Our Churches" in which he called Protestant clerics "the largest single group supporting the Communist apparatus in the United States today." 68 McCarthy, who wanted to keep him, had to yield, but the attack on churches proved to be more dangerous than attacking communists elsewhere. In March and April 1953, three months before the Matthews's affair, 51\% of Americans disagreed with a Congressional investigation in the churches, while $76 \%$ approved the same investigation in schools and colleges and $66 \%$ believed that even former members of the Communist

65 Dwight D. Eisenhower, "Letter to Mr. Harry Bullis," May 18, 1953, Dwight D. Eisenhower Presidential Library, http://www.eisenhower.archives.gov/research/online_documents/mccarthyism/1953_05_18 _DDE_to_Bullis.pdf.

${ }_{66}$ Richard M. Fried, Nightmare in Red, Ch. 5.

67 Albert Fried, McCarthyism: The Great American Red Scare, 178.

68 Richard M. Fried, Nightmare in Red, Ch. 5. 
Party should be barred from teaching. ${ }^{69}$ Americans were clearly much more sensitive to the attack on religion than on academic freedom.

Nevertheless, the greatest mistake that McCarthy made was his attack on another institution that Americans held in great esteem, the Army. It was Eisenhower who had declined to publicly condemn McCarthy, who took the action. As Albert Fried puts it: "For Eisenhower [...] this was the last straw. He was determined to bring McCarthy down." ${ }^{0}$ In the following Army-McCarthy hearings, which took place at the beginning of 1954, the defiant senator from Wisconsin lost the last vestiges of the public confidence. As early as towards the end of 1953, the support for the extraordinary legislative inquiries on communism was declining. Only $37 \%$ of Americans believed that the investigation of the communists in the government should be left to Congress while $43 \%$ believed it should be left entirely to the FBI and the Department of Justice. ${ }^{71}$ By June 1954, the respective figures were 30\% and $57 \% .{ }^{72}$ The very essence of McCarthyism, a public investigation by Congress, had lost support. There were to be no more show-trials.

\section{Conclusion}

McCarthyism placed great pressure on American civil liberties and public opinion. However, as we have seen, it cannot be said that the anti-communism of the late 1940s and early 1950s, which is undeniable, was provoked by the anti-red campaigning in the form of the HUAC hearings. It was rather a result of factors outside the US politics. The position of the domestic communists was very much connected to the image of the Soviet Union as a friendly or unfriendly power. The US politics and its inner dynamics did play their part in the way the process unfolded, but they were not the cause. The views on the domestic communists reflected the mistrust of the Soviet Union and the times of the most severe anti-communist feelings within the society coincided with the most tense moments in the international situation. The Soviet Union was viewed as the power pulling the strings attached to the communists in the US. The image of the communists and communism is, therefore, strongly linked to the image of the USSR itself.

McCarthyism affected the lives of many and that the hunt for communists meant large and extensive suppression of civil liberties. However, the suppression was far from being unprecedented and it was far from being universal. Not all

\footnotetext{
69 The Gallup Poll \#513, q. 15a, q. 15b, q. 17 (March 1953), in the Gallup Brain.

70 Albert Fried, McCarthyism: The Great American Red Scare, 179.

71 The Gallup Poll \#524, q. 11b (December 1953), in the Gallup Brain.

72 The Gallup Poll \#532, q. 7b (June 1954), in the Gallup Brain.
} 
Americans supported it, as we have seen, and courts did not affirm it. Considering the sense of an urgent threat that can be detected from the opinion polls, it is rather surprising that there were not more Americans calling for harsher methods. McCarthyism undoubtedly was a period of heightened fear which led to many unjust persecutions and personal tragedies. However, the danger was not at all imagined or fabricated. Furthermore, it never went without opposition and criticism and this critical opinion was always represented strongly, unlike the positive opinion towards the Soviet Union and communism.

\section{Biographical Note}

Jiři Pondělíček is a doctoral student of Modern History at the Faculty of Social Sciences, Charles University in Prague. He deals with the history of the early Cold War.

E-mail: j.pondelicek.jr@gmail.com 